\title{
Girls and Girls and Girls and Horses: Queer Images of Singularity and Desire
}

\author{
Elspeth Probyn
}

\section{Filles et filles et filles et chevaux: \\ Images 'queer' de la singularité et du désir}

A partir d'une réflexion sur le désir 'queer' à travers l'image de filles et filles et filles et chevaux, Probyn interprète la singularité des images dans la perspective de ce qu'elles révèlent sur le mouvement du désir, et le projet d'être. Le désir 'queer' est ici représenté par un modèle de l'identité compris comme être, ou désir - un 'be-longing' - ou pur être pris dans le désir d'être. Le projet d'être et du désir est figuré par les images des filles et chevaux. Ainsi, dans National Velvet, Elizabeth Taylor commence par rêver de monter des chevaux imaginaires, et finit par gagner le prix 'Grand National.' Ou, autre exemple, dans The Well of Loneliness, la relation très intense de Stephen Gordon avec son premier cheval... Il apparaît dans cette lecture de filles et filles et filles et chevaux que les interprétations psychanalytiques ou sémiotiques ne permettent pas de rendre compte du mouvement du désir lesbien. Les images fonctionnent en termes de mobilité, d'énergie, par les corps. Il devient ainsi possible de les envisager comme vecteurs du désir, comme relations désirantes, à la fois singulières et communes.

Like many others, I want to here address questions of identity. And like many, I am interested in articulations of queer desire. However, if the MLA bibliography is to be trusted, it seems that I am alone when it comes to my title. To be exact, there are at the moment 248 entries listed under 'horses' and 114 under 'girls,' but strangely enough my search was unsuccessful when it came to 'girls and horses' (as well as any number of permutations thereof). Putting aside this fascinating bit of sociological information, I want to briefly outline a model of thinking identity through singular images of desire. While identity can be seen to stand in for any number of terms - sexual identity, sexual preference, sexual orientation or choice - what I am primarily interested in are issues of 'belonging.' In fact, I find the term 'identity' rather staid; 'be-longing' may 
be kitch, but it captures for me some of the movement of desire, longing, nostalgia, and sheer 'being' caught up in the processes of wanting to be. Thus, this is a project of being and longing, as a girl within a culture of girls, as a woman within the historied line of desiring other women (mounted or not).

The image of horses and girls is both peculiar to me and, I think, common within 'girl-lore.' From National Velvet to My Friend Flicka, horses figure in any number of schoolgirl texts. In this texts, the reaction to puberty consists of a return, by many women, to their horse, whether imagined or real. For instance, who can forget the young Liz Taylor in National Velvet who goes from riding imaginary horses in bed to winning the Grand National? And she does so not to win the affections of Mickey Rooney but to continue a heritage of strong women. From the pony-club stories and experiences of my youth, I can only remember girls and girls together with horses, and not a boy to be seen.

Within popular culture this generalized coupling of girls and horses ('pony-mad') then operates in opposition to that of girls and boys ('boycrazy'). This dichotomy recently resurfaced in one of Nike's articulations of choice. The eight-page advertisement for athletic shoes tells the teleological narrative of women moving from girlish indecision to mature choice and 'choosing' themselves, if not choosing other women. From the agony of pimples and tits ("you got acne that was bigger than your breasts"), to the difficulty of prom nights, the ad text goes from equine images ("you wanted to own a horse/you wanted to be a horse") to images of girl-girl friendship (finding a 'best friend'), and to the loss of the best friend when 'you' become a 'steady girlfriend.' Coming across this ad, I was struck by the articulation of choice in general, and in particular by the seeming ease with which 'you' or 'us' (a collective body of flighty American girl-women) get over horses, throw over our best friends and manage to get from being a steady girlfriend to the pinnacle of being significant to ourselves. It is all represented as so straightforward, so evident. In my own queer route through adolescence to thirty something-dom, I never got over my best friend and it took me a hellishly long time to wend my way out of compulsory hetero-steadiness in order to realize the significance of women and women and me. The line about owning/being a horse vividly recalls for me the image of how girls get together with girls around horses and of how my best friend and I seemingly consciously chose each other and our ponies over boys.

I have always been fascinated by this connection of girls and girls and 
horses, body against body against body. I am far from alone in thinking that there is something wonderfully thrilling about the movement of women on women on horses. To substantiate and to titillate, I wish to offer some random equestrienne images. In The Pure and the Impure, Colette gives us a compelling description of some rather stylish fin-desiècle Parisian butches: "some of them wore a monocle, a white carnation in the button-hole, took the name of God in vain, and discussed horses competently. These mannish women I am calling to mind were, indeed, almost as fond of the horse, that warm, enigmatic, stubborn and sensitive creature,as they were of their young protégées" (65). Indeed, in Colette's terms, the horses were more worthy of love than the 'petites amies': "for these ladies in male attire had, by birth and from infancy, a taste for below-stairs accomplices and comrades-in-livery" (63). As Colette mourns the passing of what she calls "the noble season of feminine passion," she eulogizes their equestrienne, if not their lesbian, existence: "the dust of the bridle paths in the Bois still haloes, in countless memories, these equestriennes who did not need to ride astride to assert their ambiguity" (91). From her description, we can hear a seamless articulation of horses, dress and lesbian desire that allowed these women to move gracefully outside of heterosexual clumsiness. For, once "mounted on the twin pedestal of a chestnut crupper ... they were freed of the awkward, toed-out stance of the ballet dancer that marred their walk" (91).

If in Colette's description, lesbian movement flows more freely once mounted, then, in The Well of Loneliness, Radclyffe Hall substitutes horses for girls in order to aid the flow of lesbian desire. Hall effectively transubstantiates the body of Stephen Gordon's first object of desire, Collins, the housemaid, with that of her first horse: "Laying her cheek against his firm neck, she said softly: 'You're not you any more, you're Collins'" (42). As Hall puts it, "Collins was comfortably transmigrated" (42). In a later passage, horse and desire are folded upon themselves, as body upon body converse "in a quiet language having very few words but many small sounds and many small movements, that meant much more than word" (Hall cited in Whitlock, 571). As Alison Hennegan aptly states, it is a "description that can easily apply to satisfactory love-making" (cited in Whitlock, 571).

Hall's championing of theories of inversion is well-known. One might then be tempted to say that this equine transubstantiation of lover for horse fits securely within psychological substitutions of horse for 
phallus, or horse for man. However, if we pay more careful attention to the slides that are admittedly going on in Hall's text, we may be able to go beyond a pop-psychologizing, if not a rigorous psychoanalytic account, of girls and horses to the complex flow of lesbian desire. Quite simply, The Well of Loneliness makes clear that inverts are ultimately doomed to asexuality even if, following Havelock Ellis, they are of the natural order. As Jean Radford puts it, "though her inverted love is Godgiven, she [Stephen] is not, it seems, allowed to enjoy it" (107). She is, however, allowed to enjoy her love for women through her horse. While Hall is caught in the discourse of her time, she nonetheless effects an important discursive shift.

In her article on lesbian representation, Teresa de Lauretis considers how lesbian writers and artists struggle "to transcend gender and 'sex' and recreate the body other-wise" (167). De Lauretis raises the paradox (and at the same time the very condition of lesbian representation) of escaping gender by either "so disguis[ing] erotic and sexual experience as to suppress any representation of its specificity" or "by fully embrac[ing] gender, if by replacing femaleness with masculinity, as in the case of Stephen Gordon in The Well of Loneliness, and so risk to collapse lesbian homosexuality into hommo-sexuality" (160). That Hall effects this collapse is undeniable. However, I would also argue that the displacement of relations of lesbian desire from women to horses produces images of "coupled ones that do not impale themselves on the poles of sexual difference or metaphysical values, but constantly seduce the sign system" (Case, cited in de Lauretis, 168).

This is what Sue-Ellen Case calls "replacing the Lacanian slash with a lesbian bar" (Case, cited in de Lauretis, 168). And to continue in the same stylistic vein, I want to oust the Lacanian stake from the stable. To be slightly more intelligible, I want to argue that we can wrench these images away from a traditional or semiotic model of signification wherein the horse would represent the ineffable slide away from lesbian sexual specificity into hommo-sociality, as it stands in for the phallus. While the refusal of the referent is by now a commonly held postmodern a priori, the question of desire stills lurks as lack. In this scenario, the horse returns as a sign, as an interruption of the sexual relation of women to women. Against this reading, I want to propose another way of seeing images (equine and other), hence, another way of reading lesbian desire. To do so I will turn to Gilles Deleuze and Félix Guattari and consider the rhizomatic work of specific images. The rhizome is the regime of pure 
multiplicities: "an arrangement [that] in its multiplicity forcibly works on both semiotic flows, material flows and social flows" (Guattari, 65). It is thus an arrangement that no longer holds with the structuring terms, what Deleuze and Guattari call the 'three errors' of lack, law and signifier: "from the moment lack is reintroduced into desire, all of desiring production is crushed, reduced to being no more than the production of fantasy; but the sign does not produce fantasies, it is a production of the real and a position of desire within reality" (Deleuze and Guattari, 111-112). Perhaps not surprisingly, the Québécoise lesbian writer, Nicole Brossard articulates this idea in a rather more elegant way when she states: "the image is a vital resource that forms complex propositions from simple and isolated elements. Each time an image relays desire, this image thinks, with unsuspected vitality, the drift of meaning. So it is that images penetrate the solid matter of our ideas without our knowledge" (196).

The image, thus freed from its post within a structure of law, lack and signification, can begin to move across a range of places. It then causes different ripples and affects, effects of desire and desirous affects. Turning away from the game of matching signifiers to signifieds, we can begin to focus on the movement of images as engendering "relations of effectuation" and we can follow their effecting and affecting movement (Gordon in Grosz). As Elizabeth Grosz has argued, to do so is "to look at lesbian relations and, if possible, all social relations in terms of bodies, energies, movements, inscriptions rather than in terms of ideologies, the inculcation of ideas, the transmission of systems of belief or representations ..." (13). In this way, the image becomes that with which we think and feel our way from body to body, as vectors thrust forward by the energies created in their different relationships. The critical mode that can capture this movement is one that I call, after Lee Lynch's description of "cruising the libraries," a project of cruising images (410). Let me be clear that this project is not about policing images for their content. As Brossard asks, "in the very carnal night of solstice, is the image lesbian because in reproducing it I want it to be so" (196)? It is important to emphasize that images work, not in relation to their points of reference, but in their movement, in the ways in which they set up lines of desire. At the same time, this movement only occurs in and through the image's singularity, a singularity which, as Giorgio Agamben reminds us, forces us to abandon "the false dilemma" of the individual or the universal (my translation, 5). These images are exemplary, if we understand the exem- 
plary to be that "which is not defined by any property except of being said" (Agamben, my translation, 8). As Brossard writes: "the image slips, surprising re/source that slips endlessly through meanings, seeking the angle of thoughts in the fine moment where the best of intentions guiding me, worn out by repetition, seem about to close in silently on themselves. [But $t$ ] he image persists...It goes against chance, fervent relay" (196).

Thus, the images that I want to cruise are neither given by chance nor are they overdetermined. In Michèle Le Doeuff's terms, they are "winking images" (Le Doeuff, 124; see also Probyn, 1993). As Le Doeuff argues, if one looks carefully at a given philosophical or discursive system, one comes across rather errant images, images that refer to other images and knowledges outside of the text. In this movement, they allow us to see what the system cannotbring itself to say. Thus, as we consider the Hall's images of horses from our current realities, we can see them winking to the lesbian sexual relations that Hall herself could only formulate as inversion.

What I call the process of be-longing - a relational point within being and longing, a sort of queer translation of what Deleuze calls 'devenir et désir' - helps to set out the links between images, queer desire and identity (1990). I want to destabilize any notion of identity as fixed or stable. My use of images is a doubled one; it forges a movement of dédoublement caught up in the constant relations of being and becoming. "Identity," as Douglas Crimp puts it, "is always a relation, never simply a positivity" (12). I would add that the relations of identity produce images which then work in various ways. In Foucault's sense relations are precisely positive in that they produce effects and they affect us in ways we cannot always know in advance. Images, discursive and otherwise, are then considered as, what Jan Zita Grover calls, "subjunctive images - photographs hurled toward the future, cast ahead of us as visual guideposts to what we hope to become" (185).

To return to the image with which I began, images of girls and girls and horses have no essence, no fixed reference; they may individuate but they are not individual, they may be common but they are not universal. While they should not be allowed to condense into categorized notions of being, they can, however, express longing; they do throw us forward into other relations of becoming. For example, in a poem by Ruthann Robson, an image of a "stampede of wild horses" throws the narrator forward into a realization "that what you want is to become." And what 
she wants to become is caught up in the image of "two women without berets ... two mares at the river" (110). Or again, in Gloria Anzaldua's story of a woman who finally realizes she can love her lover, the final image is one of how "It would start here. She would eat horses, she would let horses eat her" (388).

Images of hope and horses. Images as vectors of be-longing, as modes of carrying me over from me to you. Images creating and expressing what Foucault called the sorts "of relationships we can set up, invent, multiply or modify through our homosexuality" (4). Images that carry with them the singularity of my mother's subjunctive statement: "if wishes were horses, women would ride."

\section{Works Cited}

Agamben, Giorigo. "La communauté qui vient. Théorie de la singularité quelconque." Futur antérieur. No. 1. (1990): 5-25.

Anzaldua, Gloria E. "She Ate Horses." In Lesbian Philosophies and

Cultures. Ed. by Jeffner Allen. New York: SUNY Press, 1990.

Brossard, Nicole. "Green Night of Labyrinth Park." In InVersions:

Writing by Dykes, Queers and Lesbians. Ed. by Betsy Warland.

Vancouver: Press Gang Publishers, 1991.

Colette. The Pure and the Impure. Trans. Herma Briffault.

Harmondsworth: Penguin, 1971.

Crimp, Douglas. "Right On, Girlfriend!." Social Text. 33 (1992): 2-18.

De Lauretis, Teresa. "Sexual Indifference and Lesbian Representation." Theater Journal. Vol. 40, no. 2. (1988): 155-177.

Deleuze, Gilles. "Le devenir révolutionnaire et les créations politiques." Futur antérieur. No. 1. (1990): 100-108.

Deleuze, Gilles \& Guattari, Félix. Anti-Oedipus: Capitalism and Schizophrenia. Trans. R. Hurley, M. Seem \& H.R. Lane. New York:

Viking Press, 1977.

Foucault, Michel. "Friendship as a Lifestyle: An Interview with Michel Foucault." Gay Information. 7 (Spring 1981).

Grosz, Elizabeth. "Refiguring Lesbian Desire." Paper presented at McGill University, 1992.

Grover, Jan Zita. "Framing the Questions. Positive Imaging and Scarcity in Lesbian Photographs." In Stolen Glances. Lesbians Take Photographs. Ed. by Tessa Boffin and Jean Fraser. London: Pandora, 1991. 
Guattari, Félix. "A Liberation of Desire." In Homosexualities and French Literature. Ed. G. Stambolian \& E. Marks. Ithaca: Cornell UP, 1979: 56-69.

Hall, Radclyffe. The Well of Loneliness. London: Corgi Books, 1968.

Le Doeuff, Michèle. L'Imaginaire philosophique. Paris: 1980.

Lynch, Lee. "Cruising the Libraries." In Lesbian Texts and Contexts. Ed. by Karla Jay and Joanne Glasgow. New York: New York University Press, 1990.

Morris, Meaghan. "Operative reasoning: Reading Michèle Le Doeuff." The Pirate's Fiancée: Feminism, Reading, Postmodernism. London: Verso, 1988.

Probyn, Elspeth. Sexing the Self. Gendered Positions in Cultural Studies.

New York and London: Routledge, 1993.

Radford, Jean. "An Inverted Romance: The Well of Loneliness and Sexual Ideology". In Jean Radford (ed.) The Progress of Romance: The Politics of Popular Fiction. London: Routledge \& Kegan Paul, 1986.

Robson, Ruthann. "Sabrina's Horses." Common Lives/Lesbian Lives. No. 42 (1992): 109-114.

Whitlock, Gillian. "'Everything is Out of Place': Radclyffe Hall and the Lesbian Literary Tradition." Feminist Studies. 13:3 (1987): 555-582. 